\title{
Portrait of a Globalized Canadian: Ken Lum's There Is No Place Like Home
}

\section{Cynthia Foo}

Volume 30, numéro 1-2, 2005

The Portrait Issue

La question du portrait

URI : https://id.erudit.org/iderudit/1069661ar DOI : https://doi.org/10.7202/1069661ar

\section{Aller au sommaire du numéro}

\section{Éditeur(s)}

UAAC-AAUC (University Art Association of Canada | Association d'art des universités du Canada)

\section{ISSN}

0315-9906 (imprimé)

1918-4778 (numérique)

\section{Découvrir la revue}

Citer cet article

Foo, C. (2005). Portrait of a Globalized Canadian: Ken Lum's There Is No Place Like Home. RACAR : Revue d'art canadienne / Canadian Art Review, 30(1-2), 39-47. https://doi.org/10.7202/1069661ar

\section{Résumé de l'article}

À l'ère de la mondialisation, que signifie le fait d'être citoyen d'une nation lorsque la souveraineté de cette dernière est constamment remise en question ? Quel portrait représenterait un " Canadien » ? Dans la photographie-panneau d'affichage de Ken Lum, intitulée There Is No Place Like Home (2000, installation à Ottawa), des portraits individuels sont couplés avec des textes qui semblent exprimer l'anxiété des sujets à propos de l'appartenance et de la localisation d'un " chez-soi ». Au lieu d'identifier et de consolider la position des sujets, l'utilisation par Lum de textes en français et en anglais déstabilise davantage leur localisation potentielle. Comme l'a noté Rosalind Krauss, l'indéniable véracité de la photographie, son statut documentaire, est fondée sur la documentation mécanique du monde; toutefois, ses objets sont régis par un langage dont le déchiffrement se trouve dans le monde au sens global (October, $\mathrm{n}^{\circ} 4$, 1997). Les performances des acteurs et actrices figurant dans les portraits renvoient à la construction de l'identité raciale dans la société au sens large; leurs traits et leurs attitudes ainsi que les énoncés qui leur sont assignés opèrent à titre de repoussoirs dans le but de fragiliser l'approbation sociale des catégories raciales.

Double sens délibéré, There Is No Place Like Home suggère un espace urbain générique à l'intérieur duquel le Canada est représenté comme une nation à l'ère de la mondialisation, une nation elle-même soumise à des pressions constitutives externes, où la notion de l'appartenance d'un individu à un lieu est déterminée par l'identité de celui ou celle qui pose la question. Dans cet article, je mettrai le travail de Lum en contexte, en le comparant à l'oeuvre de Jin Me-Yoon intitulée A Group of Sixty-Seven (1996), et celle de Jeffrey Thomas ayant pour titre Indians on Tour (2001-2002), des oeuvres produites par deux artistes canadiens qui donnent à voir le paysage urbain contemporain comme un lieu inconfortable d'identité et d'appartenance.
Tous droits réservés @ UAAC-AAUC (University Art Association of Canada | Association d'art des universités du Canada), 2006
Ce document est protégé par la loi sur le droit d'auteur. L’utilisation des services d'Érudit (y compris la reproduction) est assujettie à sa politique d'utilisation que vous pouvez consulter en ligne.

https://apropos.erudit.org/fr/usagers/politique-dutilisation/ 


\title{
Portrait of a Globalized Canadian: Ken Lum's There Is No Place Like Home
}

\author{
CYNTHIA FOO, UNIVERSITY OF ROCHESIT:R
}

\begin{abstract}
Résumé
À l'ère de la mondialisation, que signifie le fait d'être citoyen d'une nation lorsque la souveraineté de cette dernière est constamment remise en question? Quel portrait représenterait un « Canadien »? Dans la photographie-panneau d'affichage de Ken Lum, intitulée There is No Place Like Home (2000, installation à Ottawa), des portraits individuels sont couplés avec des textes qui semblent exprimer l'anxiété des sujets à propos de l'appartenance et de la localisation d'un « chez-soi ». Au lieu d'identifier et de consolider la position des sujets, l'utilisation par Lum de textes en français et en anglais déstabilise davantage leur localisation potentielle. Comme l'a noté Rosalind Krauss, l'indéniable véracité de la photographie, son statut documentaire, est fondée sur la documentation mécanique du monde; toutefois, ses objets sont régis par un langage dont le déchiffrement se trouve dans le monde au sens global (October, $\left.n^{\circ} 4,1997\right)$. Les performances des acteurs et actrices figurant dans les portraits renvoient à la construction de l'identité raciale dans la société au sens
\end{abstract}

large; leurs traits et leurs attitudes ainsi que les énoncés qui leur sont assignés opèrent à titre de repoussoirs dans le but de fragiliser l'approbation sociale des catégories raciales.

Double sens délibéré, There Is No Place Like Home suggère un espace urbain générique à l'intérieur duquel le Canada est représenté comme une nation à l'ère de la mondialisation, une nation ellemême soumise à des pressions constitutives externes, où la notion de l'appartenance d'un individu à un lieu est déterminée par l'identité de celui ou celle qui pose la question. Dans cet article, je mettrai le travail de Lum en contexte, en le comparant à l'œuvre de jin MeYoon intitulée A Group of Sixty-Seven (1996), et celle de Jeffrey Thomas ayant pour titre Indians on Tour (2001-2002), des œuvres produites par deux artistes canadiens qui donnent à voir le paysage urbain contemporain comme un lieu inconfortable d'identité et d'appartenance.
K displayed in Ottawa in 2002, presented a controversial checkerboard of text and photographs that posed questions about the stability of identity, race, and nationality. These questions have become more contentious and their answers more clearly uncertain in an era of globalization, an aspect suggested by the double-edged title of Lum's work and by the manner in which his portraits simultaneously draw from raced national stereotypes while they expose the tenuous ground of these naturalized assumptions. For this essay, I will examine the manner in which a discourse and a presentation of "Canadianness" may be seen to circulate through Lum's portraits of a suggested citizenship: portraiture that is, on the one hand, highly charged, raced, and contested and, on the other hand, may ultimately lend itself to multiple ambiguous readings in the contemporary context of global population flows and shifting notions of the "insider" and the "outsider." While the work may appear to be an unlikely candidate for a representation of a clear national portrait, I suggest that the ambiguous messages presented nevertheless offer an interpretative approach that allows for a more flexible understanding of race and national identity.

\section{There Is No Place Like Home (2000), Summer 2002, Ottawa}

Lum's work was originally commissioned for and displayed on the side of the Museum-in-Progress in Vienna in 2000. It was conceived as a variety of posters affixed to hoarding sites located across the city; however, due to political opposition, this project was realized instead as a large billboard mounted on the Mu-
seum-in-Progress. ${ }^{1}$ In its next display in Ottawa, the texts were translated into French and English and the billboard was attached to the side of the Canadian Museum of Contemporary Photography.

The work succeeded in emphasizing the official languages - not simply of Ottawa, but of Canada as well. Because of its placement in Ottawa, the work references Ottawa's geo-political locus as Canada's capital city and the site of national political power. Such a contextual reading would thus suggest that the positing of the work in this city opens up the possibility of a reading of the city's own population and makeup as synonymous with Canada's demographic of cultural plurality. This multiculturalism is an aspect of Canadian life; it is also an official government policy area. I argue that in this context, the intention of the artist to modify the initial billboard from one in which the language of instruction was English to one where French and English texts are equally represented, while certainly crucial to an understanding of the art work in its broadest sense, is not necessarily critical to a reading of this work: the Ottawa installation of There Is No Place Like Home operates within a larger institutional and cultural framework due in large part to its placement in the capical city of Canada.

The Object: Ken Lum's There Is No Place Like Home (2000)

At first glance, the work appears to be a billboard, designed after a typical advertising aesthetic: images and simple texts are paired and aligned in grid formation, and sans-serif, easy-to-read fonts are used for the texts (which are constituted as white lettering 
Figure I. Ken Lum, There is No Place Like Home, 2000. Acrylic lacquer on vinyl, $4.39 \times 20.42 \mathrm{~m}$ (approx). Ottawa, Canadian Museum of Contemporary Photography; Collection of the artist, Vancouver; and Museum-in-Progress, Vienna (Photo: Ottawa, Canadian Museum of Contemporary Photography and National Gallery of Canada).
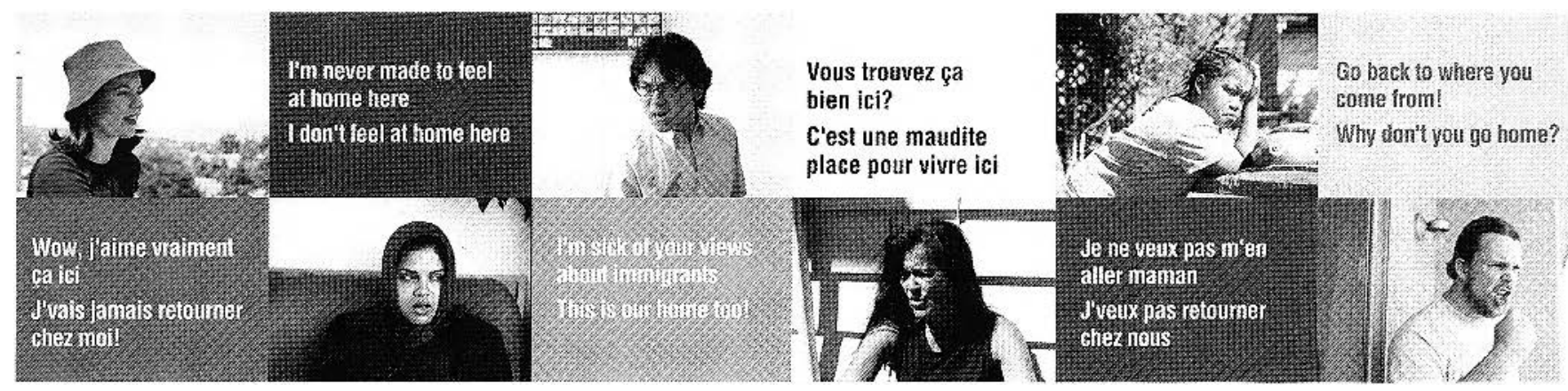

against up-beat, flat colours such as orange, green, etc.). The materials used in this work similarly borrow from established advertising conventions for the construction of billboards: indeed, the billboard's printed vinyl sheet ${ }^{2}$ is affixed to the gallery's exterior wall at a height appropriate for mass legibility.

It is this very advertising acsthetic and the work's strategic use of language that seduces the viewer into first looking at what may well be a difficult image to contemplate in a public setting. The work suggests the pairing of portraits with their appropriate texts - this pairing appears straightforward by the manner in which the sentiments expressed in the texts seemingly reflect both the race of the individuals and the emotions communicated through these individuals' facial expressions. The discomfort of viewing the work arises from the controversial nature of some of the texts. For example, an angry-looking man poses with his fist clenched, seeming to threaten a punch; in another portrait, a man looks defensively askance. Both photographs are adjacent to (and thus seem appropriately paired with) texts such as "I'm sick of your views about immigrants / This is our home too!" and "Go back to where you come from! / Why don't you go home?" One may also notice that the man with the clenched fist who is paired with the text "Go back to where you come from! / Why don't you go home?" appears to be Caucasian, while the man insisting on the rightful place of immigrants appears to be of Asian descent.

Clearly, therefore, statements of this nature pose a discomfiting challenge to any viewer who chooses to look at these unusual (and yet possibly familiar) ${ }^{3}$ portraits. The location of this work in downtown Ottawa in a highly visible public space may thus present an ethical dilemma to any viewer who may wish to pause and to contemplate this work (as one may wish to do with any work of art), since pausing to view the work may posit the viewer as a voyeur, or worse yet, as a racist, publicly enjoying the display of the discomfort of the raced individuals depicted in this billboard. However, I suggest that There Is No Place Like Home's very construction and reliance on advertising iconography interrupts the possibility of an either/or position and opens up a third category: that of the unsettled viewer, a viewer who is less able to refuse the seemingly clear-cut messages, and is instead made aware of naturalized racial stereotypes in Canada.

On one level, the work that Lum presents, while possibly appearing to be a billboard, lacks the crucial kind of advertising information one may expect, such as some kind of contact information, a telephone number, or a slogan encouraging the consumer to thus purchase or to adopt the approach of whatever depicted product or exhortation is being presented. This crucial lack of packaging information suggests a puzzle to the unwitting observer who may at first mistake the billboard for an official Canadian government advertisement extolling the virtues of multicultural tolerance through a cautionary tale of racial strife. It is both the lack of contact information as well as the explicitly racist statement "Go back to where you come from! / Why don't you go home?" that mark this work as not advertising, however. At the same time, the work's predominantly advertising-like format and reliance on the matcriality of a typical work of advertisement serve to hail the viewer and to invite him or her to look at the work. Lum's creation of an apparent advertisement stems from his ongoing engagement with the idea of photography as an element of documentary evidence.

Sometimes referred to as one of the members of the Vancouver [Photo-Conceptual] School, Lum draws on the kinds of photographically reflexive works that engage in social interpretations and depictions pioneered by Jeff Wall. Some of Jeff Wall's early works, such as Double Self-Portrait (1979) and Picture for Women (1979), demonstrate the constructedness of photographic practice and the photographs this practice produces, whilc suggesting a social commentary, much like Lum's There Is No Place Like Home. Lum's use of the advertising medium in his works also refers to the photo-collage work of artists such as Barbara Kruger, Jenny Holzer, and Martha Rosler (particularly in her work The Bowery in Two Inadequate Descriptive Systems, 1974-75). Lum's work may be read to refer to the works of Kruger, Rosler, or Holzer that engage with advertising aesthetics or media to demonstrate a concern for juxtaposing strategic 
text messages with images (or as image in the case of Holzer's work such as Messages, displayed in a variety of public locations). ${ }^{4}$

The very aim of advertising is to capture one's attention, to make one look. ${ }^{5}$ Lum's work's exclusion of contact information, which would form a key part of an advertisement (if this billboard were indeed one), may thus function on the level of parody to the spectator. ${ }^{6}$ Lum's apparent misuse of the advertising medium relies on the spectator's recognition of a conventional (billboard advertisement) format precisely in order to capture the viewer's attention. His deliberate exclusion of contact information thus renders the billboard odd, seemingly unfinished, and therefore possibly serving as an encouragement to the viewer to return repeatedly to examine what may have been initially misrecognized as an advertisement. The viewer is thus invited to openly gaze at portraits and statements that appear to be racist, without fear of being labelled a racist for examining such a work. Both the public medium of advertising and the puzzling lack of information in There Is No Place Like Home encourage precisely such scrutiny. ${ }^{7}$

\section{The Portrait, the Text, and the Viewer}

The portraits that the billboard constructs rely on understandings of race and racial stereotypes for legibility and coherence. It appears as though individuals from varied ethnic groups are equally visually represented, lending the work a quality of being considerate of a diversity of cultures. However, the pairing of text with uncomfortably appropriate photographs relies on an understanding of the unease to which visible-minority individuals are stereotypically ascribed, such as an uncertainty of belonging in a new country. The two Caucasian portraits are constructed to refer to an idea of the defensive Caucasian male insisting upon the legitimacy of his position within a nation. The similarly stereotypical portrait of the Caucasian woman speaking French suggests a caricature of white privilege when she claims to enjoy it so much "here." However, instead of appearing simply didactic, the drawing on visual and racial stereotypes in There Is No Place Like Home gives the work both its legibility and its potential to destabilize understandings of race and nationality.

By outlining each race's stereotypical visual representations, Lum's work suggests the possibility of rupturing static categories of race, and posits the mutual constructedness of any of the categories of "white," "black," "Asian," "aboriginal," with any other race-based category. In There Is No Place Like Home, Lum constructs portraits of individuals that rely on the viewer to conceptually connect portrait with text, just as it is up to the viewer to try to stitch together a narrative of the images. ${ }^{8}$ By using actors who are coded as belonging to a particular race by their skin colour, language, and religion in order to present what is clearly an illusion (i.e., a work of art), Lum's work may also thus suggest the illusive nature of race itself, since the actors inhabit roles given to them by the artist. This mimicry constitutes an outlining of an Althusseran racial ideology; what folds into this representation is thus also the allusion to real, lived racial experiences, regardless of whether the actors choose to act or not: they are coded as belonging to a race based on existing societal stereotypes and understandings of what "race" means. There is thus an inherent paradox in this suggestion of both an acted and re-enacted staging of this "narrative" of race. This paradox is what prevents the work from folding in on itself, from allowing itself to tie up and neatly present all of its messages, and from becoming visually digested and discarded. The work is thus prevented from becoming didactic precisely because of its deliberate unreadability. However, the work's use of stereotypes necessitates a spectator's engagement: by relying on pre-existing generalizations of skin colour, religion, etc., to make sense of the images and texts, the viewer's role is also important.

By both delineating and re-constructing the mechanics of this race ideology, There Is No Place Like Home is a work that involves viewer participation: in order for the viewer to understand or "read" the work, the viewer has to engage with the work using racial, class, and nationalistic stereotypes that $s /$ he had already formed before viewing the billboard. In looking at the work and understanding it, the viewer is presented with their own pre-formed ideas of the insider or outsider and the meanings of "home" and its attendant rights of belonging. Lum's work both engages the viewer as well as facilitates and permits him/her the opportunity to read and analyze stereotypical messages, whether this analysis is favourable to the treatment of visible minorities or not. There is no policing force here, no regulation occurring, either to prevent the viewer from drawing their own racist conclusions or to identify with any of the individuals depicted. The regulation that occurs, if any, is an internal mechanism, one that the work neither clearly plays to, nor obviously plays against. The work makes racism visible while at the same time permitting the controversial to be publicly scrutinized by the viewer. ${ }^{\text {? }}$

Furthermore, the portrait-text pairs may be read to stitch together a narrative describing the tensions of non-white immigration. For example, the Asian man apparently speaking English but still expressing outrage at being perpetually considered an outsider, seems to relate to, refute, and provide meaning to the portrait of the white man professing to want the country devoid of non-whites. This is but one interpretation, however. What starts becoming apparent as the viewer looks at and interprets the other texts is that the other text pairs have their own readings, that some of them may contain multiple meanings, and that the portrait pairs work against each other to both 
Figure 2. Jin-me Yoon, A Group of Sixty-Seven, 1996. Chromogenic print, $47.6 \times 60.3 \mathrm{~cm}$. Vancouver, Vancouver Art Gallery, Vancouver Art Gallery Acquisition Fund (Photo: Trevor Mills).

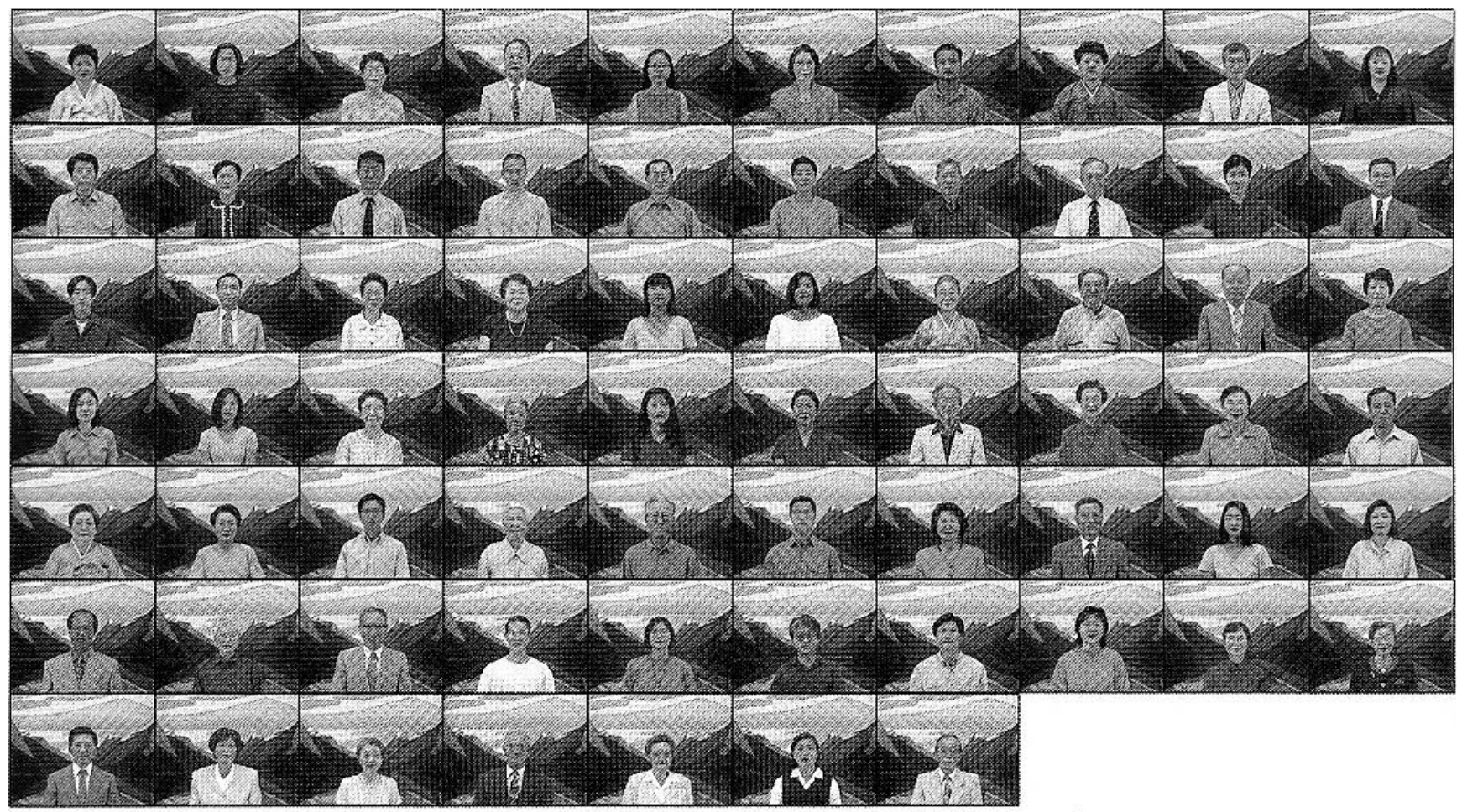

identify as well as to confuse each pair's possible readings, presenting the viewer with several means of interpreting the pairs and the work as a whole.

One example of the means by which the portrait-text pairs rely on a viewer's engagement and interpretation (and hence, a pre-formed idea of who this individual could represent) is that of the white woman in the left segment seeming to speak French. She exclaims, "Wow, j'aime vraiment ça ici / J'vais jamais retourner chez moi!" One wonders who this woman is, where she comes from that she considers "home," and where "here" is that she so appreciates. Her Frenchness is open to many different readings: she could be a resident of Quebec, of Ontario, or of any other part of Canada with a French population, in which case, each ascription of her "home" influences the meaning of the billboard, and the situation of the billboard in Ottawa, differently.

Equally possible, the woman could be tourist from France, visiting Ottawa and exclaiming her approval of the city. Indeed, she may be from any other part of the world where French is spoken, including from former French colonies such as Guyana - in which case her portrait may be seen to form a link with one of a little black girl also seeming to speak French. The little girl pleads, "Je ne veux pas m'en aller maman / J'veux pas retourner chez nous." One possible way to read this statement is with a belief that the girl may hail from a former French colony in
North Africa: perhaps from the same part of the world that the white French woman calls home.

In each of these possible readings and narrative formations, the identity of each person depends ultimately on the viewer's interpretation: many convincingly argued conclusions may be drawn from examining individual portraits, from comparing portrait-text pairs, and from trying to imagine the links between each pair on the billboard in general. What is clear is that any use of English or French text and any combination thereof, in Ottawa, on a billboard facing Parliament Hill, codes the work politically. This site-specific situating and the work's reliance on an urban spectator's understanding of the location of Ottawa as Canada's capital city, their familiarity with the icon of the billboard as part of the urbanscape, and their already formed understandings of stereotypes of national insider and outsider lend the work its readability. This readability is then troubled by a refusal on the artist's part to provide a concrete sense of place, and thus to draw the line between "outsider" and "insider." This confusing narrative (if one is to construct a narrative from the portrait-text pairs on the billboard) presents an image, therefore, of a lack of a cohesive notion of home. If it is not clear who is home and who is from away, can there be a Canadian national identity? Other artists address similar questions in their work by examining the space for race in traditional iconic representations of Canadianness. 
Figure 3. Jeff Thomas, Indian on Tour, Lausanne Switzerland, 2001, from the series Indians On Tour (2001-2002). C-print, $50.8 \times 40.64$ $\mathrm{cm}$. Bridge to The Cathedral, Lausanne, Switzerland, Collection of the artist (Photo: Jeff Thomas).

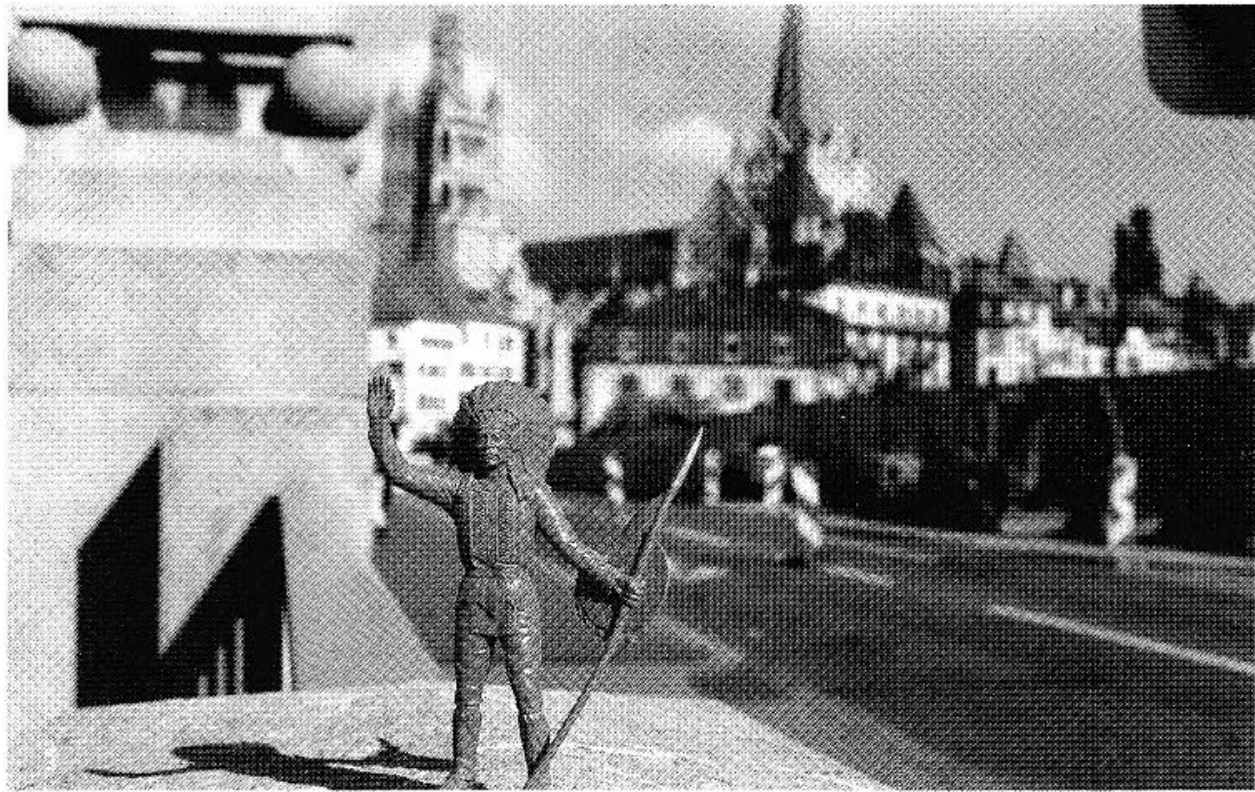

[Thomas] notes that historical portraits of Aboriginal people often excluded their immediate environment, leaving their subjects in stasis, floating in a placeless place. It is precisely the sense of immersion in an immediate, living world that he tries to capture in his own portraits. For him, contrary to the romantic notion, that world is an urban one. ${ }^{12}$

Broadly speaking, both works point to the Canadian cultural landscape as an ideological construct, which has traditionally excluded non-white individuals. In so doing, the works disturb the notion of "landscape" by opening

Consisting of front and rear head shots of Korean individuals placed in front of a Lawren Harris and an Emily Carr painting, respectively, Korean-Canadian photographer Jin-Me Yoon's work A Group of Sixty-Seven (1996) (fig. 2) posits a contemporary updating of the Canadian national identity in a rapidly changing Canada. By including images of Korean individuals against a backdrop of iconic images of Canada, Yoon points to the changing meaning of being "Canadian," questioning whether a naturalized Canadianness would include Korean faces as well. ${ }^{10}$ Yoon's work may thus be also seen to present an inherent critique of a normalized equation of "Canadianness" with whiteness. This possible critique folds into larger discussions around the place of non-white immigrants, cultural clashes, Canadian multiculturalism, and discursive practices around cultural and/or racial difference. The work thus provocatively asks whether a new paradigm of iconic "Canadianness" may be equated with Korean-Canadian faces. ${ }^{11}$

First Nations artist Jeffrey Thomas's work points to the absence of representations of the urban First Nations individual to emphasize naturalized equations of the "Native" as an individual who is rural and primitive. In his series Indians On Tour (2001-2002) (see fig. 3 for an example from the scries), Thomas photographed toy figures of stereotypical Indian braves in various urban settings around the world, suggesting that the imagined location of the "Indian" is one fixed in the past. His series highlights an absence of a visual vocabulary to represent a contemporary urban "Indianness" as something other than an anachronism. Richard Hill, commenting on Jeffrey Thomas's depictions of the "Indian" states, up an alternative reading of this ideology, suggesting that the contemporary "landscape" is one which has changed from its historical moorings. The co-existence of Koreanness and an iconic Canadianness may therefore not be a natural one, since these two identities are set up to occupy separate spheres in Yoon's work, and since the iconic Canadian is called forth as white only via the contrasting presence of the Korean individual in A Group of Sixty-Seven: the "white" person is made present through the oddness of the image of the Korean portraits set in front of Harris's painting. The jarring juxtaposition of the Korean individual against Harris's painting suggests an unease in a co-existence of the "racialized" individual with the kind of Canadian landscape Harris painted. This friction echoes contemporary political and social tensions involving naturalized and unquestioned assumptions of the ethnicity of the typical Canadian citizen, and thus the place for the "raced" individual within Canadian sociery.

Thomas's work, on the other hand, subverts the historical caricature of the Native as the "brave" in order to disturb essentialist readings of "Indianness." His work also suggests the location of the "Indian" in urban culture to both broaden the definition of "Indian" as well as to disrupt the location in which this "Indian" may exist. No longer is the "Indian" relegated to the mythical camp fires and the tiipis of yore; here the toy Indian brave standing in for the Indian is instead displaced from the urban environment, and yet a part of it. Thomas's work suggests the primacy of the urban condition, replacing a rugged landscape for a mass-media influenced one as he places the plastic figurine of the "Indian" in global, urban locations of Lausanne or Buffalo. 


\section{The Global Citizen}

The notion of a concrete or stable national identity is one that continues to be hotly debated, particularly in an age of rapid international flows of people immigrating, working, and moving between countries. ${ }^{13}$ This movement often disrupts understandings of who belongs where, thus presenting a site of disruption to a stable or naturalized understanding of the race of a national citizen. For example, one might pose the question, when one is asked to imagine a "Canadian," does an image of a non-white Canadian automatically come to mind? The appearance of Lum's billboard as a federally-sponsored multicultural advertisement as one possible initial reading of the work seems plausible, given the choice of individuals representing different racial, ethnic, and religious backgrounds, and the equally weighted use of English and French texts. This project may thus seem iconically "Canadian," and my argument for a globalized reading may therefore seem contradictory. However, the effects of globalization, rather than creating "either/or" results - producing either a total erosion of the nation-state, or one which results in an homogenizing, unstoppable "McDonaldization" effect - instead result in multiple and heterogeneous tensions.

The makeup of what is termed "globalization" contains multivalent forces and reactions that work with pre-existing national structures to produce hybrids, homogenizations, Westernizations, and reinterpretations. In some instances, the process referred to as "globalization," rather than simply acting as a unidirectional force upon a culture, instead results in reconstitutions and reinforcements of pre-existing regional and/ or national identities. John Tomlinson's model of globalization describes an uneven process that results in a variety of responses, regardless of inherent power imbalances, particularly in the experiences of less-Westernized countries, ${ }^{14}$ while Nederveen Pieterse suggests that the effects of globalization are affected by regional understandings and reactions that reinterpret and refigure what may seem to be a homogenizing impulse into specific regional, hybridized responses, a process which he argues "gives rise to a global mélange." 15 He states, "Globalization can mean the reinforcement of, or go together with, localism, as in 'Think Globally, Act Locally." 16 As such, a specifically Ottawa-based Canadian reading of Lum's work as an understanding of globalization is not necessarily inherently contradictory. Globalization is not likely a uni-directional process of standardization, but rather results in a "multi-centric world of diverse actors such as corporations, international organizations, ethnic groups, churches" that are in turn nested within larger "-scapes" such as "financescapes" or "ethnoscapes." 17

While the literature describing the anxieties and impacts of globalization is varied, the common element is an assertion that "globalization" is neither a generic container describing a gen- eral set of global interconnections, nor are these global interconnections, on their own, the source of current anxieties around nationness, home, and belonging. Rather, it is the nature of 1970 s post-Fordist globalization that is at issue: it is this intensification of global connections which so inflames anxieties around stable notions of nation, national identity, and belonging. ${ }^{18}$ I suggest that it is post-Fordist globalization that is also linked to the Canadian federal government policy of multiculturalism, a set of policies that has come to bear on a now steadily increasing influx of non-white immigrants to Canada.

Canada's official policy of multiculturalism, historically initiated as a means by which to designate Canada an officially bilingual country with a multicultural populace, ${ }^{19}$ has come to account for the diversity of the Canadian population, a diversity that has increased since 1970 because of the steady acceptance of larger proportions of non-white immigrants to white immigrants. ${ }^{20}$ The process of immigration is a demographic change, which is itself a result of the economic, political, and social forces of globalization. ${ }^{21}$ Saskia Sassen remarks,

What we still narratc in the language of immigration and ethnicity, I would argue, is actually a series of processes having to do with the globalization of economic activity, of identity formation. Too often, immigration and ethnicity are constituted as otherness. Understanding them as a set of processes whereby global elements are localized, international labour markets are constituted, and cultures from all over the world are dc- and re-territorialized, puts them right there at the centre along with the internationalization of capital as a fundamental aspect of globalization. ${ }^{22}$

Populations drawn from different regions in the world may also maintain stronger international ties than local ones, creating trans-national communities that further diminish the power of the nation-state to construct and reproduce a concrete, shared understanding of nationhood. ${ }^{23}$ Discussing the role of a perceived shared citizenship, Holston and Appadurai assert,

This notion [of citizenship's commonly-held principles] requires a set of self-understandings on the part of cirizens that lies at the core of the liberal compact of citizenship: it requires that people perceive, through a kind of leap of faith, that they are sufficiently similar to form common purpose. This perception is sustained in the long-run through performance of citizenship. ${ }^{24}$

\section{The Globalized Canadian Citizen?}

Canada's policy on multiculturalism, when related to immigration and the presence of non-white individuals (as Lum depicts 
on his billboard), thus folds into international entanglements with global capital and labour flows. Indeed, Lum's billboard itself becomes a marker of the nature of being Canadian as an "un-homed," possibly transient member always in the process of being defined against others, rather than as a citizen who fits into a tenable, stable national rubric. In this context, then, Lum's work may paradoxically propose a re-imagined Canadian national identity as one that is constructed precisely from disparate fragments. Rather than a possible "united in diversity" reading of multiculturalism (and therefore, of an idealized notion of Canadian citizenship), There Is No Place Like Home instead erodes a static sense of "home," a sense of the "nation," and thus also of a clear sense of which individuals are seen as "citizens."

Further, while Canadian official policy on multiculturalism promotes "unity in diversity," this approach has been criticized as one that normalizes and perpetuates an invisible whiteness, ${ }^{25}$ a normalization that may indeed be inevitable as a result of the burden of Canada's white-centric past, ${ }^{26}$ which continues to replicate and perpetuate static categories of race and whiteness, even if for the purposes of addressing racially based barriers to entry. ${ }^{27}$ Globalization is perhaps one means by which to disrupt and re-interpret a notion of the Canadian citizen as precisely an individual whose race is unclear. Rather than to conclude that this unstable position is ridden with anxiety, I would like instead to suggest that the instability of a national identity offers some possibilities for re-imagining nationhood as a porous entity, citizenship as a legal formality, and the portrait of a Canadian citizen as contingent on context and in relation to other citizens.

Lum's There Is No Place Like Home thus answers as it questions: there is no (such) place as "home," if this home or nation is to be reliant on a homogenous understanding of belonging (this approach which thus redraws the boundaries between insider and outsider). At the same time, there is also no (better) place (than) home, this mythical, comfortable dwelling that proposes to welcome as it insists upon a definition of rightful possession. Fraught as it is with anxieties, displacements and porous borders, a globalized model of Canadian citizenship may thus suggest a model in which seemingly fixcd identities are fixed only in relation to others. The idea of "race" and "nation" then become linked to other individuals within the nation, rather than to specific locales. Furthermore, while the model of globalization presents possible disruptions to nationhood and citizenship (i.e., suggesting that anyone can belong anywhere they can move to, as though their decision to move involves nothing other than desire), it also contains within it highly classed, gendered and raced undercurrents, along with those also of violence and trauma. I in no way wish to romanticize the plight of refugees or exiles but instead to put forward the possibility of re-thinking Canadian nationalism and na- tional citizenship, suggesting the possibility of extending, disrupting, and muddying these categories from an either/or dichotomous model.

\section{Acknowledgements}

This essay is based on work completed in 2004 towards the fulfillment of the Master of Arts degree in Art History from York University in Toronto. The master's research was supported by a SSHRC CGS Master's Scholarship. The author wishes to thank Karen Stanworth and Kitty Scott for their helpful feedback and editing advice during her Master's degree writing process, and to thank Janet Berlo for her insights and suggestions during the writing of this essay. She would also like to express her gratitude to the RACAR editorial board and to Lara Perry and Eva Major-Marothy for their patience and sense of humour during the revision process.

\section{Notes}

1 E-mail communication between Ken Lum and Cynthia Foo, 30 October 2003, used with permission of the artist. The MuseumIn-Progress is an experimental art space founded in 1990, which "organizes exhibitions in media such as newspapers, magazines, billboards, the facades of buildings, TV and the internet and thereby integrates art into everyday life. The museum of the $21 \mathrm{st}$ century exists as a flexible structure and establishes the form in which it appears directly in media space." See its website for more information: http://www.mip.at/en/index.html.

2 For a description of the materials used, see Ken Lum Works With Photography, exh. cat., Ottawa, Canadian Museum of Contemporary Photography (Ottawa, 2002), 94.

3 I do not wish to suggest here that the familiarity of the portrait-text pair is through a viewer's position as a possibly racist individual, but to highlight instead the stereotypes (and therefore, the possible familiarity of the coding of these images) that these seemingly natural connections draw from. Clearly as well, the placement of a photograph adjacent to a text also suggests an explicatory link between the portrait and the text.

4 For a description of where Holzer's text, "Protect Me From What I Want," was displayed in its 1988-89 version, see Artangel's website: http://www.artangel.org.uk/pages/past/88/88_holzer.htm.

5 In Michael Argyle and Mark Cook, Gaze and Mutual Gaze (Cambridge, 1976), 113, the authors remark: "There appears to be a (unwritten) rule that one should not gaze at strangers in public places, for example when standing in lifts, passing in the street, or sitting opposite at tables in restaurants or libraries. Goffman calls this 'civil inattention,' and observes that the difficulty of observing it may be eased by adopting other activities, involving attending to objects." As such, the photographs representing "reality" are made acceptable as a subject of interrogation. That the subjcct material is troubling is a secondary register once the viewer's gaze has been 
successfully engaged. The reference in the quote to Goffman is attributed to the monograph Erving Goffman, Behavior in Public Places (Glencoe, 1963).

6 "The work to be parodied is decoded by the parodist and offered again (encoded) in a 'distorted' form to another decoder, the reader, who - knowing and having previously decoded the original - is in a position to compare it to its new form of parody." See Margaret A. Rose, Parody/Metafiction: An Analysis of Parody as a Critical Mirror to the Writing and Reception of Fiction (I.ondon, 1979), 26.

7 The manner in which one is allowed to look in public is elaborated in Argyle and Cook, Gaze and Mutual Gaze, 113. The viewer may thus be aware of the manner in which his/her gaze may be construed as being in collusion to the statements displayed on Lum's billboard.

$8 \mathrm{I}$ am referring here to Althusser's assertion that once ideology is exposed, the "reality" of the situation may be uncovered: "We commonly call religious ideology, ethical ideology, legal ideology, political ideology, erc. so many 'world outlooks'. . . . However, while admitting that they do not correspond to reality, i.e., that they constitute an illusion, we admit that they do make allusion to reality, and that they need only be 'interpreted' to discover the reality of the world behind their imaginary representation of that world (ideology = illusion/allusion)" [original emphasis]. Althusser also asserts that "Ideology is a 'Representation' of the Imaginary Relationship of Individuals to their Real Conditions of Existence." I.ouis Althusser, "Ideology and Idcological State Apparatuses (Notes towards an Investigation)," Essays on Ideology (London, 1984), 36.

9 "When observers feel observed, or are at risk of losing face, they became uncomfortable." D.R. Rutter, Looking and Seeing: The Role of Visual Communication in Social Interaction (Chichester, 1984), 108. The production of discomfort would then allow the viewer to look away, but if the viewer is not at risk of "losing face" and is allowed to look at seemingly controversial statements, they can then examine the statements at length.

10 "Yoon's work does not point to essentialized concepts of identity; rather, it speaks of the complexity of Canadian identity as it conflicts with, includes and reconsiders multiculturalism." Adrienne Lai, "Renegotiating the Terms of Inclusion: Institutional Space, (dis)location and A Group of Sixty-Seven," Fuse 23, 1 (April 2000), 19.

11 There are many other nuanced interpretations of Yoon's Group of Sixty-Seven work that have been omitted for brevity here, including a suggestion of Yoon's engagement with the idea of Koreanness in itself, or a repudiation of multiculturalism, among two possible readings. See Lai, "Renegotiating the Tcrms of Inclusion," for a discussion of these readings.

12 Richard Hill, "Jeff Thomas: Working Histories," in A Study of Indian-ness, exh. cat. Toronto, Gallery 44 (Toronto, 2004); http:// www.gallery 44.org/exhibitions/brthomas.htm.

13 Saskia Sassen has written extensivcly on the movement of people as a result of international capital investment. See Saskia Sassen, The Mobility of Labor and Capital. A Study in International Investment and Labor Flow (Cambridge, 1998).
14 "Globalization is an uneven process, not just that it involves 'winners and losers' or that it reproduces many familiar configurations of domination and subordination, but also in the sense that the cultural experience it distributes is highly complex and varied." John Tomlinson, Globalization and Culture (Chicago, 1999), 131. However, I disagree with Tomlinson's assertion here that globalization "distributes" a cultural experience, since his model doesn't take into account the regional pushes that influence an cxternal homogenizing impulse, as Nederveen Pieterse suggests.

15 Jan Nederveen Pieterse, "Globalization as Hybridization," The Globalization Reader, eds Frank J. Lechner and John Boli (Massachusetrs and Oxford, 2000), 99. First published in M. Featherstone et al., eds, Global Modernities (London, 1995).

16 Pieterse, "Globalization," 102.

17 Pieterse, "Globalization," 103. See also Arjun Appadurai, "Disjuncture and Difference in the Global Cultural Economy," The Globalization Reader, 322-30, for the original source of the terms and descriptions of ethnoscapes, mediascapes, etc. and the cffect of globalization in these arcas.

18 For an explanation of the difference in intensity in post-Fordist global interconnections contrasted with historical accounts of cultural contact, sec Neil Brenner, "Global, Fragmented, Hierarchical: Henri Lefebvre's Geographies of Globalization," Public Culture 10, 1 (1997), 136-67, or Appadurai, "Disjuncture and Differcnce," 322-30. Appadurai argues that it is the scalc of interactions and their intensity that has changed, not global interaction per se, and suggests that the great organization difficulty and cost of having global interactions in the past are removed with technological advancements such as international air travel and global teleand media-communication networks.

19 Prime Minister Pierre Trudeau had "announced in the Canadian parliament the policy of multiculturalism within a bilingual framework." Introduction to Racial Minorities in Multicultural Canada, eds Peter S. Li and B. Singh Bolaria (Toronto, 1983), n.p. See also J. Arthur Lower, Selections from Hansard: House of Commons debates, 28th Parliament, 3rd session October 8, 1971 -June 30, 1971 (Toronto, 1971).

20 "For the past 60 years of the past century, European nations such as the United Kingdom, Italy, Germany and the Netherlands, as well as the United States, werc the primary sources of immigrants to Canada. Today, immigrants are most likely to be from Asian countries ... Of the 1.8 million immigrants who arrived between 1991 and 2001, 58\% came from Asia, including the Middle East; 20\% from Europe; $11 \%$ from the Caribbean, Central and South America; $8 \%$ from Africa; and 3\% from the United States. . Just $3 \%$ of immigrants who came to Canada before 1961 were Asianborn." Statistics Canada, 2001 Census: Analysis Series: Canada's Ethnocultural Portrait: The Changing Mosaic (Ottawa, 2003), 6. The report also states on p. 10: "In 2001, three-quarters (73\%) of immigrants who came in 1990 s [sic] were members of visible minority groups. This was an increase from 1991 when $68 \%$ of those who came in the 1980s were visiblc minorities and in 1981, $52 \%$ of those arriving in the 1970 s."

21 "The shift during the past 40 years has been due to a number of 
factors, including changes in Canada's immigration policies and intcrnational events related to the movement of migrants and refugees." The report also states that in tcrms of numbers of immigrants, "[Immigration] flows had not becn this high since the beginning of the century." Statistics Canada, 2001 Census.

22 Saskia Sassen, "Whosc City Is It? Globalization and the Formation of New Claims," The Cilobalization Reader, 73. First published in Globalization and Its Discontents (New York, 1998).

23 James Holston and Arjun Appadurai, "Introduction: Cities and Citizenship," Cities and Citizenship, ed. J. Holston (Durham, 1999), 1-18. The authors assert that liberalism's version of equality in citizenship has been repeatedly exposed not to work in the way it is presented, particularly for immigrants and de-territorialized workers. They continue, "As a result, the project of a national society of citizens, especially liberalism's twentieth-century version, appears increasingly exhausted and discredited," and continue, "In other places, the nation may maintain the envelope of citizenship, but the substance has been so changed or at least challenged that the emerging social morphologies are radically unfamiliar and force a reconsideration of the basic principles of membership," 2.

24 Holston and Appadurai, "Introduction," 6.

25 See, for example, Richard. J.F. Day, Multiculturalism and the History of Canadian Diversity (Toronto, 2000).
26 I use the term "white-centric" here with an awareness of Canada's historical distinctions betwcen different kinds of whiteness: for example, Italian-Canadians, Polish-Canadians, or Ukrainian-Canadians were not considered as racially desirablc as (Anglo-Saxon) British-Canadians, (Teutonic) Gcrman-Canadians or ScandinavianCanadians. Attitudes towards German-Canadians as "more desirable" than other "white" races change after the first and second World Wars. See Harold F. Harney and Harold Troper, Immigrants: a Portrait of the Urban Experience, 1890-1930, (Toronto, ca. 1975).

27 See, for instance, the Canadian Employment Equity Act, which defines "visible minorities" as "pcrsons, other than Aboriginal peoples, who are non-Caucasian in race or non-white in colour." This statement makes "whiteness" an unruptured category, one that simply exists, rather than one that is itself understood to be a "race," if race is to be used as an identifier. The Act also relies on a present and continued understanding of "race" in order to combat it - an inherently contradictory position that nevertheless needs stability in order to combat real, lived race-bascd barriers to employment. The difficulty is in not perpetuating white-centric terminology and ideology, such as "non-white," or determining "Caucasianness" while at the same time addressing systemic, racebased imbalances. 